\title{
Smokeless Tobacco and Teenagers
}

\author{
Marieh Honarmand (iD 1, \\ ${ }^{1}$ Department of Oral Medicine, Oral and Dental Disease Research Center, School of Dentistry, Zahedan University of Medical Sciences, Zahedan, Iran \\ "Corresponding author: Department of Oral Medicine, Oral and Dental Disease Research Center, School of Dentistry, Zahedan University of Medical Sciences, Zahedan , Iran. \\ Tel: +98-9151423019, Email: honarmand56@yahoo.com
}

Received 2019 August 30; Revised 2019 November 06; Accepted 2019 November 13.

\section{Dear Editor,}

Oral soft and hard tissue conditions are two equally important aspects of dental sciences. There are numerous studies on dental caries as the most prevalent infectious disease (1). There are also several surveys pertaining to acquired oral soft tissue lesions and their causative factors. One of these factors is Smokeless Tobacco (ST). Smokeless tobacco includes a variety of tobacco products that are consumed by chewing, keeping in the mouth, or sniffing rather than smoking. Smokeless tobacco products are used by 356 million people in over 140 countries in the world. Most ST users (82\%) live in Southeast Asia where the use of ST is incorporated with cultural traditions (2). The proximity of Sistan and Baluchistan province, Iran, to Afghanistan and Pakistan and the illegal import of these products into deceptive packages and their distribution in the market have increased the consumption of these materials. Therefore, the author decided to deal with this issue.

Smokeless tobacco products contain betel quid, tobacco, flavorings, and lime. Based on the materials used in each product, they have different names, such as Paan and Gutka. This material has been considered by the WHO as "carcinogenic to individuals" and has been associated with oral and pancreatic cancers, periodontal diseases, cardiovascular disease, and asthma (3).

Scientific documents suggest that it is as dangerous and addictive as cigarette although the users believe that the ST use is safe. Low-weight birth, stillbirth, preterm birth, and small-for-gestation age can be considered as the pregnancy-related consequences of ST consumption (2). It has been shown that ST consumption is one of the most common causes of oral cancer $(4,5)$. Some of the oral lesions related to ST include Smokeless Tobacco Keratosis (STK), gingivitis, periodontitis, bone resorption, dental caries, dental erosion, mucosal dysplasia, and Squamous Cell Carcinoma (SCC) (6).

The use of ST by children and young adults can be due to the design of these products that is appealing to young people. Some types of ST brands are produced by tobacco companies in fruit and candy flavors (7). Since these substances cover the unpleasant taste of tobacco, it is easier for children to use, paving the way for addiction. Sugars, acetaldehyde, menthol, and methyl salicylate as favoring constituents of tobacco products can still show sensory and pharmacological impacts. Tobacco-pH lowering by sweeter flavors can increase craving to starters. On the other hand, some sugars can impress the free-nicotine amount (8). People may are not aware of the dangerous effects of using these substances (9) and use these products for various beliefs, such as freshening the mouth, aiding digestion, enhancing the mood, reducing stress, pleasant taste, and oral health (3).

The primary purpose of substance abuse prevention is to support individuals, particularly young people, to avoid or delay the initiation of drug use or, if it has started already, to prevent dependence. The general purpose of substance abuse prevention includes the strong and harmless development of children and the youth to realize their talents and potential and to become the members of their society (10).

Strategies that contain impressive tobacco control plans include media programs, increasing the tobacco price, evidence-based school packages, and sustained society-wide endeavor.

\section{Footnotes}

Conflict of Interests: The author declares no conflict of interest.

Funding/Support: There was no funding for this study.

\section{References}

1. Ramazani N, Rezaei S. Evaluation of the prevalence of clinical consequences of untreated dental caries using PUFA/pufa index in a group of Iranian children. Iran J Pediatr. 2016;27(1). doi: 10.5812/ijp.5016.

2. Siddiqi K, Mishu MP. Smokeless tobacco: Why does it need special attention? Respirology. 2019;24(8):720-1. doi:10.1111/resp.13612. [PubMed: 31195425]. 
3. Banerjee SC, Ostroff JS, Bari S, D’Agostino TA, Khera M, Acharya S, et al. Gutka and Tambaku Paan use among South Asian immigrants: A focus group study. J Immigr Minor Health. 2014;16(3):531-9. doi: 10.1007/s10903-013-9826-4. [PubMed: 23579964]. [PubMed Central: PMC4097304].

4. Gupta PC, Pednekar MS, Parkin DM, Sankaranarayanan R. Tobacco associated mortality in Mumbai (Bombay) India. Results of the Bombay Cohort Study. Int J Epidemiol. 2005;34(6):1395-402. doi: 10.1093/ije/dyi196. [PubMed: 16249218].

5. Honarmand M, Hajihosseini A, Akbari F. Oral cancer knowledge of senior dental students in Zahedan, South-East of Iran. Asian Pac J Cancer Prev. 2014;15(7):3017-20. doi: 10.7314/apjcp.2014.15.7.3017. [PubMed: 24815440].

6. Glick M. Burket's oral medicine. 12th ed. USA: PMPH; 2015.116 p.

7. Brown JE, Luo W, Isabelle LM, Pankow JF. Candy flavorings in to- bacco. N Engl J Med. 2014;370(23):2250-2. doi: 10.1056/NEJMc1403015. [PubMed: 24805984].

8. Kostygina G, Ling PM. Tobacco industry use of flavourings to promote smokeless tobacco products. Tob Control.2016;25(Suppl 2):ii40-9. doi: 10.1136/tobaccocontrol-2016-053212. [PubMed: 27856998]. [PubMed Central: PMC5433525].

9. Honarmand M, Farhadmollashahi L, Bekyghasemi M. Use of smokeless tobacco among male students of Zahedan universities in Iran: A cross sectional study. Asian Pac J Cancer Prev. 2013;14(11):6385-8. doi: 10.7314/apjcp.2013.14.11.6385. [PubMed: 24377537].

10. Gates S, McCambridge J, Smith LA, Foxcroft D. Interventions for prevention of drug use by young people delivered in non-school settings. Cochrane Database of Sys Rev. 2006;(1). CD005030. doi: 10.1002/14651858.CD005030.pub2. 